\title{
Silver Fruit plate Owned by Khedive Isma'il, The Silverware Museum of 'Abdeen Palace in Cairo
}

Prepared by

Mohammed Farghal Zaki Mousa

PhD Researcher - Tourist Guidance Department

Faculty of Tourism \& Hotels - Minia University

\section{Introduction}

This research deals with the study a masterpiece from the silver masterpieces of Muhammad Ali Dynasty, preserved at the silverware Museum in 'Abdeen Palace ${ }^{(1)}$ (Cairo), this masterpiece was from the belongings of Khedive Isma'il, who ruled Egypt between 18 January 1863 A.D, was removed on 26 June 1879 A.D, and died on 2 March 1895 A.D. The masterpiece is one of the silver belongings of the Khedive Isma'il candlestick is first published in this research

\section{The importance and objectives of the research}

- To highlight the importance of the silver collection of 'Abdeen museums ${ }^{(2)}$ and try to preserve it at its best.

- To show how much the rulers and princes of Mohammed Ali's dynasty were fond of collecting artifacts made in Europe or Egypt similar to the forms of Europe. Such fondness reflects the high social level of Mohamed Ali's dynasty especially during this period which witnessed a big openness to the West encouraged by this family.

- It sheds light on new technical aspects that were not known in Egypt till the rule period of Muhammad Ali's dynasty in the early $19^{\text {th }}$ century.

- These objects are of a special nature whether in forms, methods of decoration and manufacture which Egypt has not seen before, but were transferred to it due to influences from modern European styles. 
- I have noticed that most of the studies related with the family of Muhammad Ali almost focused on the historical and architectural aspects, and just a little of them dealt with their artistic aspects.

- The large quantity of metal objects belonging to the family of Mohammed Ali is in a good condition preserved in 'Abdeen palace museum. Most of these objects were not studied before, so I chose them as a topic of my study.

\section{The descriptive study}

Kind of artifact: plate

Code No.: 1107290038

Type No.: $34 / 2$

Place: 'Abdeen palace museums, silverware museum, hall No. 1, showcase No.1.

The owner: Khedive Isma'il ${ }^{(3)}$

Material: silver

Dimensions: height 90 c.m, plate diameter 42 c.m

Weight: 15.905 K.G

Manufacturing region: Prussia ${ }^{(4)}$

Dating: $2^{\text {nd }}$ half of the $19^{\text {th }}$ century

Publishing: $1^{\text {st }}$ published

Description: (Pl.1)

Holder of a fruit plate with a circular base implemented at two levels, the lower level mounted on 6 legs in the form of animal legs, topped with vicious floral motifs and floral patterns. These vicious motifs topped by wreath of fruits. The second level of the base is a short cylindrical part decorated with 3 decorative forms resembling the handle of the vessel executed in the style of Baroque and Rococo. Between these figures there is a medallion decorated with the royal crown, the symbol of the Egyptian state in the era of Khedive Ismail, and two Latin letters IP, abbreviation of the name and title of Khedive Ismail in English Isma'il Pasha. The base is surmounted by a column surrounded by five human figures of children with joined hands. The pillar ends with palm fans mounted with a round dish with a diameter 
of $42 \mathrm{~cm}$ with two knobs surmounted by two parrots with long tails. The outside of the dish is decorated with a decorative frame with fruit and floral motifs, from the edge of the dish are two ornamented triangular shapes of modified plant elements. A palm tree in the centre of the dish emerges; with open palm fans in the middle. The column extends to the top, ending with incomplete palm fans to settle on the human form of a woman carrying by her hands cornucopia and the other hand a fruit plate.

\section{The analytical study}

It is possible to study the aforementioned masterpiece analytically through the form, function, and material, as well as the decorations implemented on them, like floral motifs, living organism motifs, and writing inscriptions.

\section{First: the artifact in terms of form and function}

There are many forms of metal dishes made in the era of Muhammad Ali family and there is a close relationship between the shape of the dish and its function, because the lack of depth shows us that this form of dinnerware was designed to put food free of broth and often may be dedicated to the meat and on the other hand, Large diameters are likely to have been used for fruit development ${ }^{(5)}$.

The shape of the fruit plate in question appeared during the reign of Khedive Ismail (1863-1879). The royal crown of the Alawite family and the literal IP are abbreviated to the name of Khedive Ismail Pasha in Latin letters. The museum records show that this type of dish is made by Prussia.

\section{Second: the artifact in terms of material:}

Silver is known to be a precious metal used by man since the dawn of history ${ }^{(6)}$. Silver is chemically symbolized by Ag. It is a brilliant white metal found in nature in the form of pure or non-pure metal. In the first case, silver is pure in the form of mesh crystals, wire, or tree and rarely found in the form of small blocks, or thin sheets. In the second case, silver is found in gold in different proportions that may reach a significant degree, as it is found in sulfide and silver chloride, and is found in a very small percentage in the ores of lead and nickel, and in varying proportions in copper and zinc $^{(7)}$.

In ancient Egypt, silver was considered a kind of gold, so it was called white gold as it contained a percentage of gold ranging between $9 \%$ and $38 \%$, and the name of white gold, which the ancient Egyptians called the silver metal may be because they were found In the same 
places to find gold, so they were considered gold of the lowest degree characterized by the colour white ${ }^{(8)}$.

Silver is unique from other metals with many features that made it used in various purposes, and perhaps the most important of these properties is its silver colour, which is not worn or tainted by the opacity, as well as the flexibility and extensibility ${ }^{(9)}$ and not affected by water and air and they are not oxidized if heated in the air or in the atmosphere ${ }^{(10)}$ It is a good conductor of heat and electricity ${ }^{(11)}$. Pure silver is usually found with copper to increase its hardness, and is mixed with gold to increase its hardness ${ }^{(12)}$.If a little copper is added to it, it helps to reduce its melting temperature, prevents bubbles from freezing the alloy, and increases its hardness without material impact on its colour or Roadworthiness ${ }^{(13)}$.

It has been used in Egypt since the early Islamic era in the manufacture of antiques from dishes and other, and reached a high degree of artistic mastery, especially during the era of the Fatimid caliphs ${ }^{(14)}$. It was second only to copper in terms of the use of metal utensils in the Ottoman era where it was used in the manufacture of jewellery and ornamental tools such as ankles and pots such as conditions and jugs; also used in the manufacture of weapons such as sheaths swords and daggers ${ }^{(15)}$.

It is interesting to note that the use of silver in metal utensils in Egypt during the late Ottoman and Muhammad Ali dynasties is noteworthy, despite the fact that this material is not available in it, which confirms that these artifacts were made in Europe or purchased directly from European markets. Manufactured in Egypt.

\section{Third: motifs executed on artifacts:}

The motifs on the artifacts under study are divided into vegetal motifs, living creature's motifs, and inscriptions.

\section{- Floral motifs}

It refers to all ornaments or decorative ornaments based on its drawing or inscription on plant elements or parts such as stems, leaves, flowers and fruits of various forms or images, whether in their natural form or modified in the form of abstract symbols far from their original nature. In the Absolute Plants are decorations of the earth, adorned with, and beautified for human enjoyment ${ }^{(16)}$, and the idea of quotation of plant elements from the decoration to the Pharaonic, Assyrian and Chaldean times, as found in the Hellenistic era and also the Hellenistic arts in the East ${ }^{(17)}$, and plant decoration played a prominent and important role In the decoration of fixed and movable Islamic monuments, Islamic art has been 
influenced by Eastern Greek art, especially Roman Hellenistic art, as well as authentic Oriental art, especially Iraqi and Iranian ${ }^{(18)}$, these decorations composed from trees, leaves, fruits and roses ${ }^{(19)}$.

Botanical decoration is one of the most important types of decoration used in the arts of civilizations prior to Islam, and known as Acantus leaves and grape leaves and branches and palm fans in addition to various forms of trees and fruits and others. These elements have moved from Byzantine and Sasanian art to Islamic art ${ }^{(20)}$.

However, the Muslim artist did not convey these plant elements in the same form as they were in previous civilizations, as he made adjustments that lost a lot of their initial forms, helped by the depth of his faith and the delicate sense and accuracy of his feelings and love for nature, all of which had the effect of creating many types of decoration Plant. In addition to the emergence of plant decorations influenced by European models of Baroque and Rococo in various forms.

\section{1- Palm trees (pl. 4)}

The Palm is mentioned in many locations of the Wise and symbolizes prosperity, as the inhabitants of the Sahara can only bear fruit in their power. And considered by Muslims of the trees of paradise and therefore painted on various products such as carpets and others. The palm trees are ancient symbols, as they are found on the inscriptions of the Assyrians in Mesopotamia in the first millennium BC, drawn by the Ottomans in turn on their artifacts, and are represented in large numbers on the artifacts studied $^{(21)}$.

\section{2- Flowers (pl. 2, 4)}

Baladi rose flowers were among the favorite decorative elements in Turkish art, and were used by the Turks a lot in their art, and began to use in the classical phase of Ottoman art in the mid-16th century in a more natural way can be seen in the decoration and art during this period of Turkey has become easy Distinguishing the types of flowers from each other, and perhaps the reason for this is the keenness of the sultans of AlOthman to cultivate and grow them in the royal gardens to enjoy them, which led to the large number of floral drawings on the Ottoman arts, whether in the manuscripts, murals or applied artifacts.

Roses are considered one of the most used flowers in the work of metal pots and it is noted that roses centred on nature was more widespread than rose's simulated nature. Not only did the manufacturers represent their drawings according to the known implementation methods, but they formed parts of some types of pots in the form of a rose, especially the handles of the lids of jugs and saucers. Moreover, the manufacturers carried out multi- 
petal roses and overlapping roses on top of each other as well as roses inside some of them and also carried out roses of colour Different ${ }^{(22)}$.

\section{3- Fruits (Pl. 2, 4)}

Fruit was used as a decorative element, and in the twelfth century $\mathrm{AH} / 18 \mathrm{AD}$, the tendency towards nature prevailed, and the ornamentation of the fruit abounded, and they chose the types that are characterized by their round shapes, and were implemented without musical leaves and paint these types of fruit naturally realistic and not decorative ${ }^{(23)}$.

In the work of the metal pots multiple types of fruit fruits, the most important are grapes, cherries, pomegranates, and pine cobs ${ }^{(24)}$. On the fruit plate is the grapes and cherries.

\section{4- Leaves (pl. 2, 4)}

The infinite forms of plant leaves occupied a prominent place in the work of metal pots, where the manufacturers implemented palm fans, halves and quarters, palm fronds, grape leaves, Romans, orris, cloves and roses. Most of these leaves are in the composition of composite motifs $\left({ }^{25}\right)$.

\section{5- Baroque and Rococo (pl. 2, 4)}

The word Baroque is derived from the Portuguese word Barroco, meaning rough ${ }^{(26)}$ or coarse pearl. This word was called decorative style prevailed Catholic architecture in Portugal, Spain, Italy and some countries of Europe from the late sixteenth century until 1720. Its decorative elements include snails, seashells and swastika as the main elements of decoration (27). The Baroque style was often described as the architecture of curves, exaggerating the decoration of buildings with huge winding scrolls in imaginary and exotic shapes, generously detailed carved ornaments and stranded columns ${ }^{(28)}$. This style has spread in some European countries more than others, where it was widespread in France, and rarely used in Italy and the Netherlands, and remained in Germany and England until the end of the 18th century, and this style was popular in Turkish architecture and decoration ${ }^{(29)}$. This style was transferred to Egypt in the era of the family of Muhammad Ali and his children because of their aspiration to this European civilization and trying to push the country towards it. This style was evident in the palaces of the nineteenth and early twentieth century and the various palaces contained in these palaces.

The word Rococo is derived from the English word Rock, which means stone, or the word Rocallie, which means irregular shell ${ }^{(30)}$, a trend popular in Europe during the period from about 1730 to about 1780. The art of Rococo is an advanced stage of Baroque art where it is characterized by its hatred for the use of straight lines and its love for curved and spiral lines, 
but it is distinct from Baroque art in its direction towards agility and tenderness ${ }^{(31)}$.

Baroque and Rococo motifs represented many of the artifacts of the Muhammad Ali family, especially those made of silver. It should be noted that metal artifacts were the most appropriate applied arts to implement Baroque and Rococo motifs.

\section{- Motifs of living organisms:}

The decorations of living organisms were used in conjunction with other motifs, although these motifs did not reach the amount of other motifs in terms of use, where we note the scarcity of use of motifs of living organisms represented in human and animal motifs in addition to motifs of birds, although what we got from these motifs A clear indication of what was characterized by these decorations of characteristics and features reflect the ability of the artist and enable him to his tools.

\section{1- Human figures}

The use of human drawings on many of the arts applied in the era of the family of Muhammad Ali, like the human figures of children with joined hands as well as a statue of a woman on the fruit holder carrying by her hand cornucopia and the other hand a fruit plate. $(\mathrm{Pl} .3,5)$

2 - Birds figures

Note the use of birds appears on the plate where the figures of the parrots with long tails against each other. (Pl.4)

\section{- Royal Crown}

The royal crown is always the symbol of the monarchy. It is also a symbol of the Egyptian state during the reign of Khedive Ismail. It was widely used on flags and emblems, and was a favourite decoration among the princes of the family of Muhammad Ali, indicating the king, sovereignty and domination, as it was used on many materials of applied arts. The candlestick appears on the subject of the study. (Pl. 7)

\section{- Written motifs}

There are two Latin letters IP surmounted by the royal crown, abbreviation of the name and title of Khedive Ismail in English "Isma'il Pasha", where the first letter was taken from the name "Isma'il", and the first letter of the title "Pasha", and notes the presence of relief of letter I and existing parts of the letter P, I have noticed this abbreviation signifier Ali Khedive Ismail himself and the same directive outlet grooving in his other 
silver masterpieces in the same collection in the museums of the Abdin Palace.

It is a European tradition that was commonly used at the time as a signature in the initials of the name of the person who owns the piece. They were often shaped like a monarch and decorated with the royal crown and the name of the masterpiece. $(\mathrm{Pl} .7)$

\section{Conclusion}

Through my previous study of the masterpiece, it is clear that the importance of the study of these wonderful artifacts, and the study of the masterpiece has yielded a descriptive and analytical study of many of the results that I would like to highlight the following:

- To shed light on the historical and archaeological significance of this collection, the silver processing centres and the methods of decoration and decorative elements.

- The decorative elements on the silver masterpiece under study inside the Abdeen Palace museums were divided into three types of floral, written motifs as well as living organisms.

- The study confirmed that the inscriptions on the silver masterpiece under study in the form of the initials sign that the piece belongs to Khedive Ismail IP.

- I noticed many European influences on the masterpiece under study we find it in the form of masterpiece, where some of the forms of a unique character known for the first time in Egypt were implemented on candlesticks.

- All the metal collections displayed in the Silver Museum in Abdeen palace museums are made of silver, although the raw material is not available in Egypt to confirm that the centres of manufacturing these artifacts were in Europe.

- European influences are also found in the decorations where they concentrated in the use of the Baroque and Rococo represented in the forms of beds and often formed an oval inside the royal crown and the name of the masterpiece, as well as drawings of statues, whether statues of human or animal or statues of fairy beings, also not to leave space No decoration, which led to the repetition of decorative elements, and decorative elements, which is one of the European influences that were common in Europe and moved to Egypt is the design of the legs of some artifacts in the form of legs of animals, as well as bouquets of flowers and flowering branches. 
- The 13th / 19th century is considered an important and dangerous turning point for Islamic architecture and arts in Egypt, where this period of Egypt's history witnessed an openness to the various European currents in all its forms, where Islamic arts were affected in this period and the period after the nineteenth century and the first half of the twentieth century. The European currents also witnessed a significant transformation in the materials used, in the forms of antiques, in the ornamentation executed, as well as in the methods of industry and decoration. 


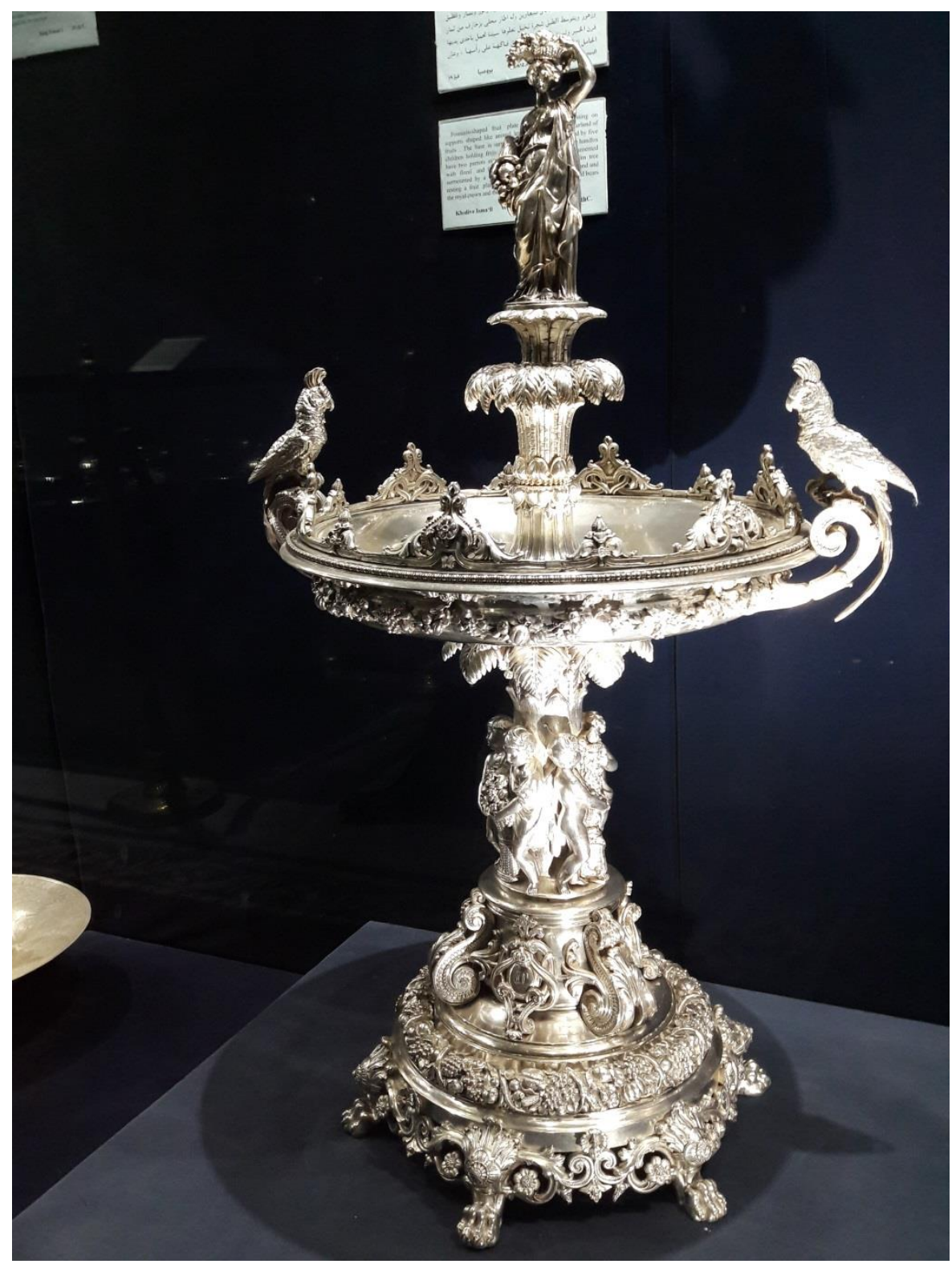

Pl.1

Cairo, Abdeen palace museums, silverware museums, hall.1, showcase No.1, silver fruit plate owned by Khedive Isma'il dates back to $2^{\text {nd }}$ half of $19^{\text {th }}$ century

(By the researcher) 


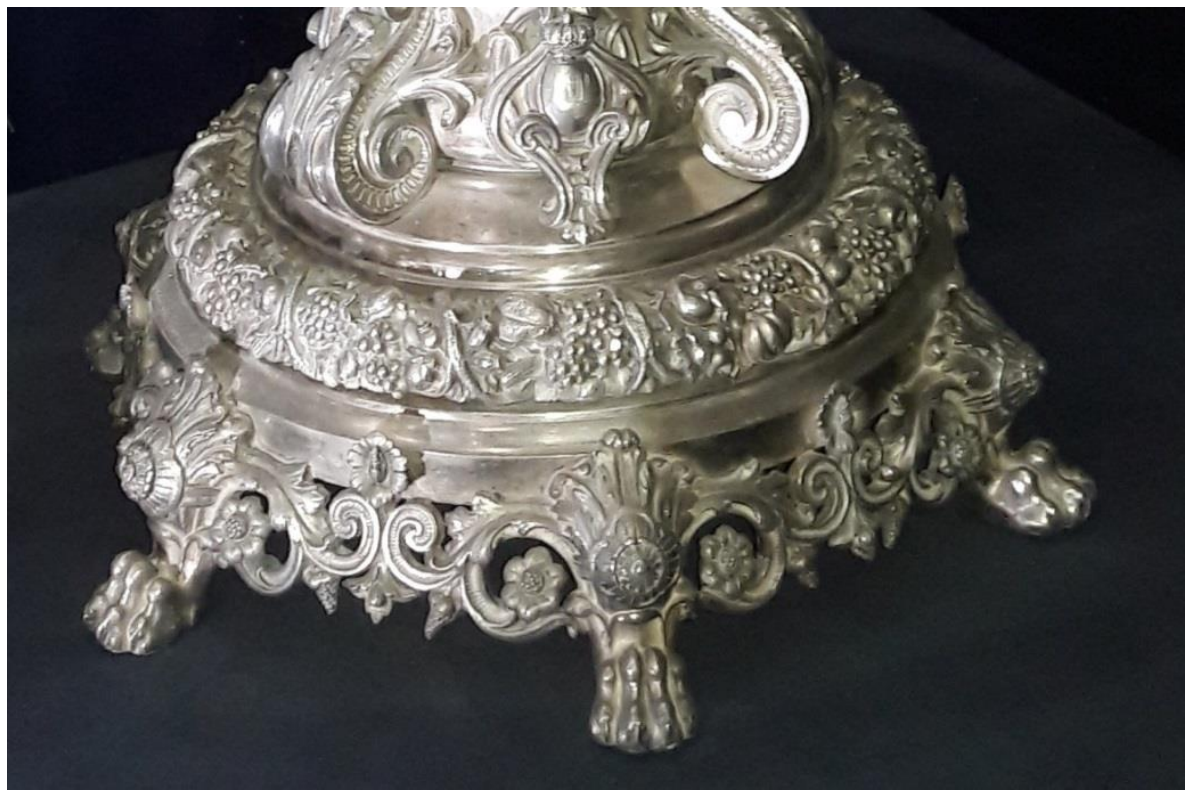

Pl.2

Circular base of the fruit holder mounted on legs in the form of animal decorated with a wreath of fruits

\section{Pl.3}

A column of fruit plate surrounded by five human figures of children with joined hands

(By the researcher)

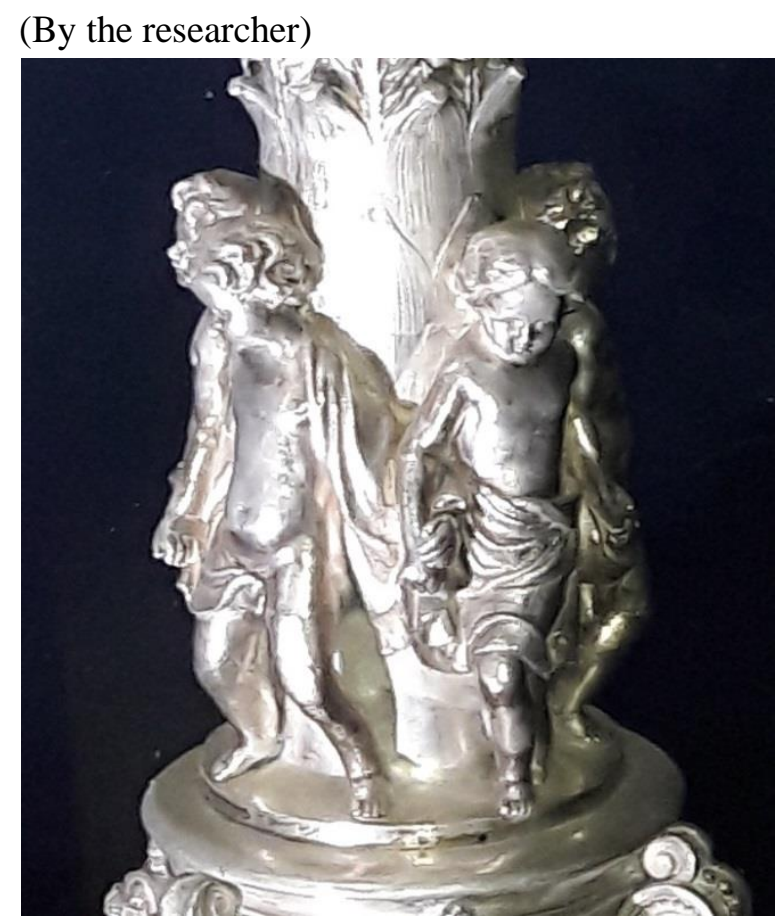




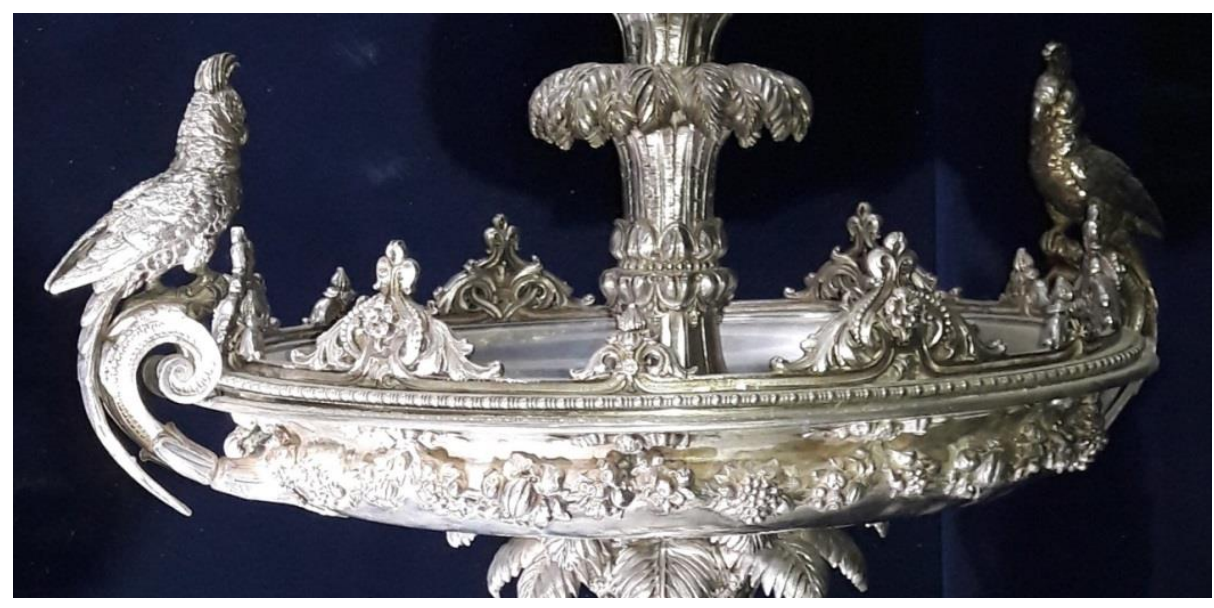

\section{Pl.4}

A round dish with a diameter of $42 \mathrm{~cm}$ with two knobs surmounted by two parrots with long tails and the outside of the dish is decorated with a decorative frame with fruit and floral motifs, A palm tree in the centre of the dish emerges

(By the researcher)

\section{P1. 5}

A woman carrying by her hands cornucopia and the other hand a fruit plate.

(By the researcher)

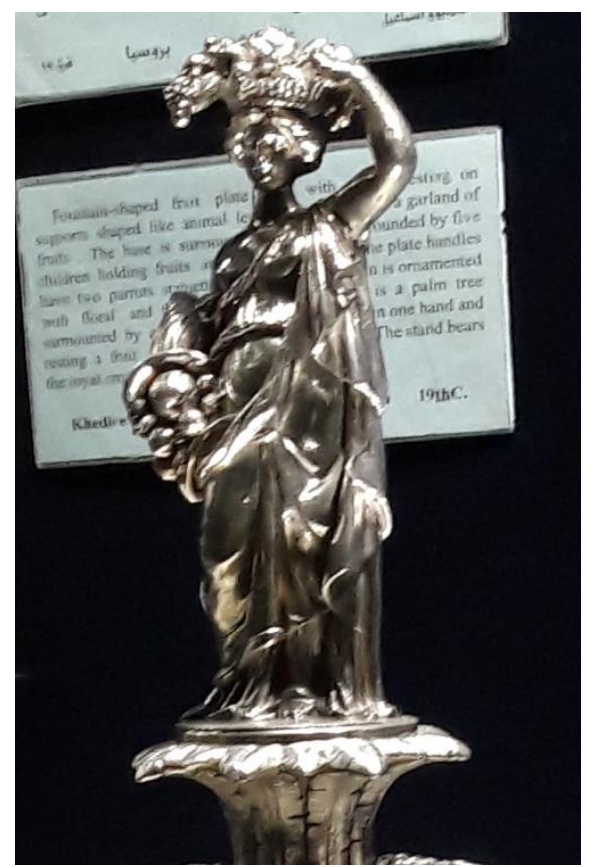




\section{Bibliography}

(1) 'Abdeen Palace is one of the most important and famous palaces constructed during the reign of the family of Muhammad 'Ali Pasha of Egypt. Khedive Isma'il started to build this palace immediately after his ascendance of the throne in 1279 A.H / 1863 A.D, and took it as his official residence in 1291 A.H / 1874A.D. It was mainly built to transfer the official royal residence from the citadel to the city center of Cairo.

It was called 'Abdeen Palace because it was built on the ruins of a house owned by "'Abdeen Bik "a Turkish prince whose position was "Amir al-liwa al-Sultani". Khedive Isma'il bought the house from him and also expropriated hundreds of other buildings and routes around them to increase the whole area to 24 acres. The palace took ten years to build, and was carried out by Engineer De Corel wel Rousseou, and a huge number of Egyptian, Italian, French and Turkish painters. The palace building cost 700.000 pounds, while the furniture cost 2,000,000 Egyptian pounds. Although the Khedive lived in the palace and transferred the official royal location to it, the palace kept its old name 'Abdeen, which included also the square and the entire quarter.

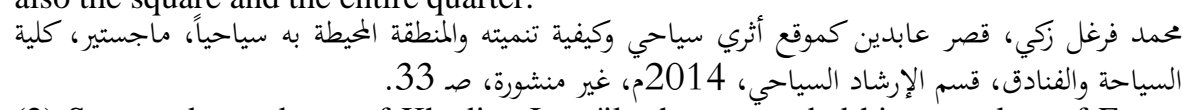

(2) Sons and grandsons of Khedive Isma'il who succeeded him as rulers of Egypt were fond of adding their own touches to "Abdeen palace to reflect the taste and spirit of the era. For example, King Fouad I, Isma'il's son, who ruled Egypt from 1917 A.D to 1936 A.D, assigned some of the Palace's rooms as a museum for the Royal Family's possessions, including weapons, ammunitions, decorations, orders and medals. His son Farouk I, who succeeded in ruling between 1936 A.D and 1952 A.D, completed the museum, adding many possessions, in particular all kinds of weapons. He also annexed to the museum a library with references specialized in weaponry.

The management of 'Abdeen Palace museum in the wake of the July 1952 Revolution was assigned to the Museums Department in the Citadel. Afterwards, President Sadat assigned the museum management to the Presidency of the Republic and ordered to restore and renovate the palace and its museum. At the time of the Ex-president Hosni Mubarak, another two specialized museums were also established, One for gifts received by Presidents of Republic on various national occasions or during their worldwide tours, the other for Muhammad 'Ali Pasha's possessions including utensils and vessels made of silver, crystal and colored glass, as well as other unique artifacts. They were established under the name "'Abdeen Palace Museums" and were re-inaugurated by President Mubarak on October 17, 1998 A.D.

On December 16, 2004 A.D, a specialized museum for historical documents was established. It is one of the most important sections of the museums for visitors as well as researchers in this field.

محمد فرغل زكي، قصر عابدين كموقع أثري سياحي وكيفية تنميته والمنطقة الميطة به سياحياً، صـ 114،114. (3) Ismail Ibn Ibrahim Ibn Mohammed Ali was born in the palace AlMusaferkhana in the district of Jamaliya in Cairo on 17 Rajab year $1245 \mathrm{AH} / 12$ January 1830 AD. His father, Ibrahim Pasha, had three children, among them Ismael, the eldest Ahmed Refaat and the youngest Mustafa Fadel, two half-brothers of Ismail. His father raised him to learn the principles of science, Arabic, Turkish and Persian languages, and a little mathematics and nature. Then his parents sent him to Vienna, Austria, to be treated by the rag of Siddie. He was fourteen years old. He spent two years and then moved to Paris to join the fifth Egyptian mission known as the Angal Mission. His brother Ahmed Rifaat and Prince Abdel Halim and Hussein, sons of Mohammed Ali, received in Paris luck of engineering, mathematical and natural sciences and mastered the French language, and also 
attended the military school of the Military College of Saint-Sir, and then Ismail returned to Egypt during the reign of his father Ibrahim Pasha. When Ibrahim and his successor Abbas 1 died, Ishmael and his sisters felt hatred of Abbas. Muhammad Ali died, and the rivalry between Abbas and the rest of the princes increased. Ismail traveled to Astana and was appointed by Sultan Abdul Majid as a member of the Ottoman State Council and blessed by Bashawiya. Ismail did not return to Egypt until Abbas was killed. . During the reign of his uncle Said Ismail received a strong sympathy and entrusted to him to head the Council of Judgments, and sent him in $1271 \mathrm{AH} / 1855 \mathrm{AD}$ on a political mission to Napoleon III, Emperor of France.

Ismail was not thinking of the throne after Said because his brother Ahmed Rifaat was older than him and he was crown prince, but his brother was killed in a train accident, where the vehicle carrying him fell in the Nile at Kafr El-Zayat and drowned during his return from Alexandria in $1275 \mathrm{AH} / 1858$, Thus, Ismail became Crown Prince, and made him his deputy during his absence from Egypt twice, the first during Said's visit to Syria in 1276 AH / 1859 AD, and the second during his visit to Medina in 1277 AH / 1861 AD. After the return of Said from Medina, Ismail made a sardar for the Egyptian army, and entrusted him to quell the sedition of some tribes in Sudan, and Ismail put it out without shedding blood. When Said died behind him Ismail in the throne of Egypt on January 18, 1863 AD. The governors of Egypt were called Aziz, the governor or the Pasha, while Ismail Pasha was the first to receive the title of Khedive, and the state of Egypt became an explicit legacy in his descendants from which he passed on to his eldest children, according to the firman of June 8, 1873.

Since Ismail came to power, he is determined to give Cairo a modern face, which is clearly visible today, as he has been associated with a comprehensive project to modernize the city to complement the larger project "Modern Egypt" initiated by his grandfather, Mohamed Ali Pasha. The Cairo project included the city's palaces, public and administrative buildings, parks, utilities, and bridges that Cairo needed most as the capital of the east.

As for the work of Ismail in all fields can be considered a golden age in the progress of urbanization in the Egyptian country has been interested in expanding the property of Egypt in Africa, and took care of the strength of the war and naval countries, and interested in science and literature, where he reorganized the School of Medicine and the School of Engineers during 1865, and established many Higher schools such as administration, tongues, rights, space, accounting, and Dar al-Uloom, and the first school for girls in Egypt, the Sioufi school, was established. He also took care of the means of transport, where he expanded railroads. He also bought the Italian post offices. The central building of the post office was built at the doorstep in 1874, in addition to public buildings such as the Arab Antiquities House and the Khedive Opera House. Clot Bey, Faggala, Abdul Aziz. A number of parks were constructed such as Azbakia, Orman and the zoo, and new neighbourhoods such as Ismailia, Azbakia, Abdin, Faggala and Qasr Al Nil Bridge and Al Galaa Bridge were established. He was interested in the establishment of palaces where he built many luxury palaces that were the most important features of his era such as the Palace of the island, Abdeen, the dome and saffron, Ismailia, and Giza.

At the end of his reign, as a result of the financial crisis, European countries increased their pressure and interference in the country's internal affairs, namely the establishment of a debt fund, the imposition of bilateral control over Egypt's finances, and the appointment of two European ministers in the Egyptian government. When Ismail felt the weight of these countries, and the restrictions imposed on him, he sought to get rid of it with the support of the nationalists, but European countries, especially England, France and Germany sought at the High Gate until it was able to obtain a firman to depose Ismail on June 26, 1879, and he left Egypt in exile to Naples, where he prepared The King of Italy has his own palace to live with him and his family, and then he moves around in European capitals. In $1305 \mathrm{AH} / 1888 \mathrm{AD}$, he moved to Astana and lived in the Palace of Emperor Gyan on the Bosphorus.He remained in Astana until he died on March 2, 1895. He was 65 years old.Then his body was transferred to Egypt on 10 March. His funeral was officially held in Alexandria and then Cairo where he was buried. Rifai Mosque. See:

- أمين سامي، تقويم النيل، مطبعة دار الكتب، 1916-1936 ، الجزء الثالث، المجلد الثاني، صـ 440 ، 


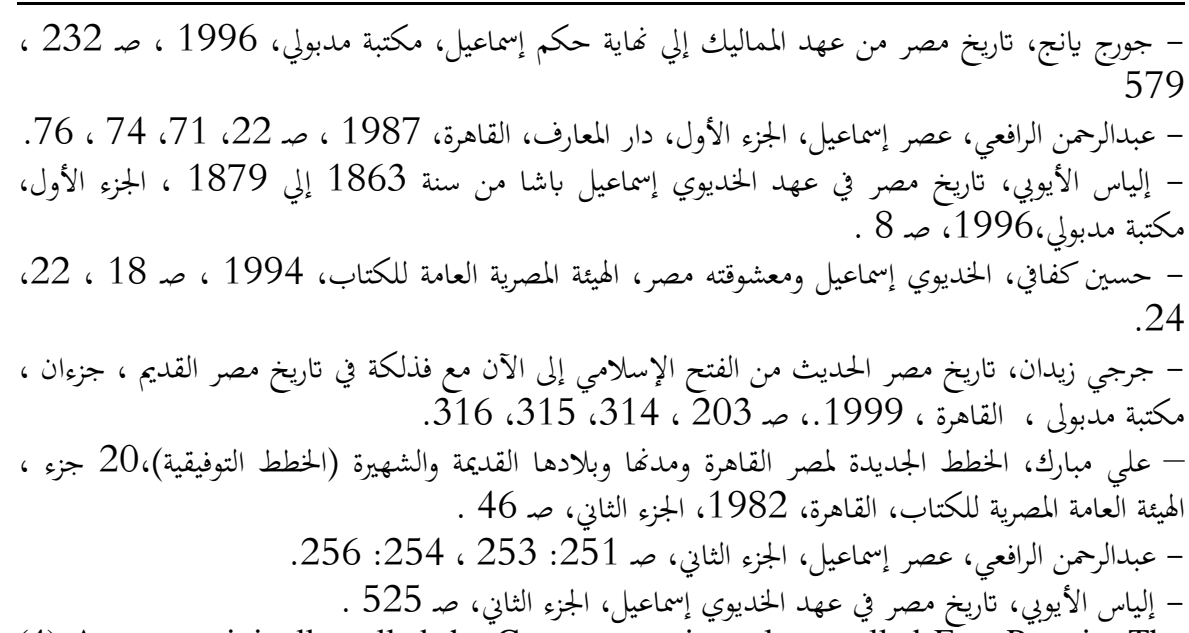
(4) A name originally called the German province, later called East Prussia. The area is named after the Prussian indigenous Baltic people. Since 1225, it became the center of the state of the Knights of the German Order, and then divided into two parts, one starting in 1466 as Royal Prussia under the authority of the Polish Crown, and the other since 1525 as the Principality of Prussia after secularization of the rest of the Knights State. In 1618, the Principality of Prussia annexed the Brandenburg Electoral Principality. Brandenburg, which was founded in 1157, has ruled the Hohenzlern dynasty since 1415. The territory of Brandenburg at the time of the accession of King Friedrich to the throne, as well as the electoral principality of Brandenburg and the Principality of Prussia, the maximum Pomerania, Magdeburg, Minden-Ravensburg, the Principality of Mark and the Principality of Kleve. See:

- Clark, Christopher: Iron Kingdom: The Rise and Downfall of Prussia, (16001947), 2006.

- Robertson, Charles, Grant: The Evolution of Prussia, the Making of an Empire, Rev. ed. Oxford, Clarendon Press, 1946.

- Fueter, Eduard: World history, 1815-1920. United States of America: Harcourt, Brace and Company, 1922, pp. 25-28, 36-44.

$$
\begin{aligned}
& \text { سعيد مصيلحي، أدوات و أو اني المطبخ المعدنية المملوكية، در اسة أثرية فنية، رسالة دكتور اه، جامعة }
\end{aligned}
$$

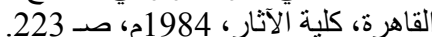

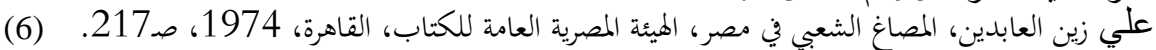

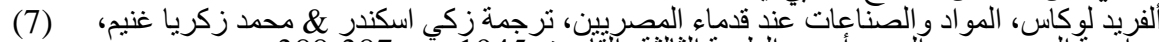

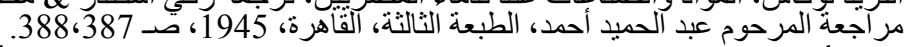

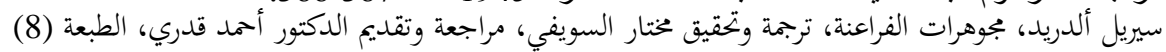

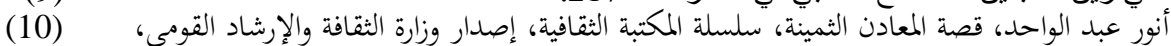

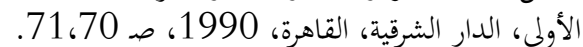

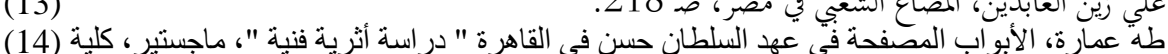

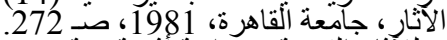

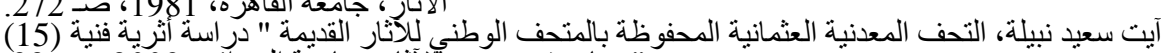

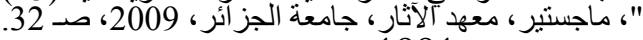

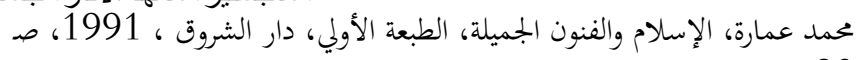


هبة مسعد إبراهيم، قصر الأميرة سميحة كامل، ماجستير ، كلية الآثار، جامعة القاهرة، 2009، صـ (17) .222

$$
\text { عاصم محمد رزف، معجم مصطلحات العمارة و الفنون الإسلامية، الطبعة الأولي، مكتبة مدبولي }
$$

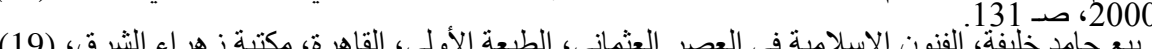

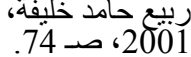
عبد الناصر ياسين، الفنون الزخرفية الإسلامية بمصر في العصر الأيوبي، دار الوفاء لدنيا الطباعة والنشر، (20) الأسكندرية، 2002، صـ الناصن 375

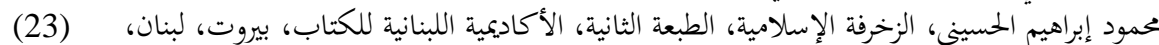

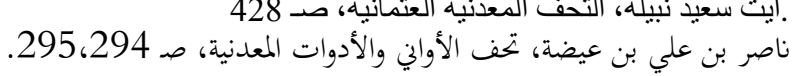

$$
\begin{aligned}
& \text { 1991، صـ } 12 .
\end{aligned}
$$

(27) Toman, R, Baroque Architecture, Sculpture, Painting, France, 1998, P.8.

مرفت عبد الهادي، الزجاج التركي العثماني من خلال مجموعات متاحف القاهرة دراسة أثرية فنية، رسالة (28)

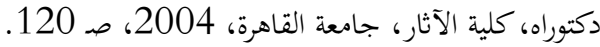

(29) Reffat, T, M, Twentieth Century Islamic Architecture in Cairo, The American university in Cairo Press, 1992, P.8

نعمت إسماعيل علام، فنون الغرب في العصور الوسطي والنهضة والباروك، الطبعة الثالثة، دار المعارف، (30)

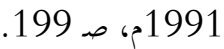

$$
\text { محمد عبد العزيز مرزوق، الفنون الزخرفية الإسلامية في العصر العثماني، صـ } 58 .
$$

